\title{
LIPOSUCTION \\ KEMAJUAN DALAM TEHNIK OPERASI
}

\author{
Jan T. Ngantung \\ Bagian Ilmu Bedah Fakultas Kedokteran Universitas Sam Ratulangi Manado \\ Email: jtngantung@yahoo.com
}

\begin{abstract}
Liposuction -lipoplasty (fat modelling), liposculpture, suction lipectomy, lipo (suction-assisted fat removal)- is a cosmetic surgery operation that removes fat from many different sites in the human body. After thirty years of improvements, more fat cells can now be removed more easily, with less blood loss, less discomfort, and less risks. Recent developments suggest that the recovery period can be shortened as well. As with any surgery, there are certain risks, beyond temporary and minor side effects. Careful patient selection and the usage of clinically proven procedure minimize their occurrences. Liposuction procedures depend on available choices of operations and the condition of patients.
\end{abstract}

Keywords: liposuction, fat, operation technique

\begin{abstract}
Abstrak: Liposuction merupakan tehnik operasi kosmetik yang mengeluarkan lemak dari berbagai tempat di dalam tubuh. Setelah perkembangan selama 30 tahun maka lebih banyak sel-sel lemak di dalam tubuh yang dapat dikeluarkan dengan lebih mudah, lebih sedikit terjadi kehilangan darah, serta lebih kurang ketidak nyamanan dan resiko. Demikian pula masa penyembuhan menjadi lebih singkat. Seperti halnya tindakan operasi lainnya, liposuction juga tidak lepas dari terjadinya resiko. Dengan seleksi pasien yang ketat dan penggunaan tehnik operasi yang telah terbukti hal tersebut dapat ditekan. Pemilihan jenis liposuction disesuaikan dengan jenis tindakan operasi yang tersedia dan keadaan pasien.
\end{abstract}

Kata kunci: liposuction, lemak, tehnik operasi

Dewasa ini liposuction telah menjadi jenis operasi plastik yang paling populer dan mendunia. $^{1-6}$ Diperkirakan 500.000 liposuction dilakukan di Amerika Serikat setiap tahun, dan lebih dari 150.000 di Jerman. ${ }^{1}$ Tujuan melakukan liposuction adalah untuk mengurangi jaringan lemak yang terlokalisir di antara kulit dan otot untuk memperoleh suatu kontur tubuh yang proporsional serta transisi yang mulus antara area yang dilakukan liposuction dan yang tidak dilakukan. ${ }^{1,2}$ Sepuluh tahun terakhir ini liposuction telah dilakukan lebih sering pada penyakit-penyakit seperti giant lipoma, symmetrical lipomatosis (Launois-Bensaude syndrome), buffalo neck pada sindrom Cushing, lipomatosa dolorosa (Dercum's disease), gynaecomastia atau lipomatosis, serta pada lipedema dan beberapa bentuk limfedema. ${ }^{1,7}$

Walaupun tehnik operasi liposuction bukan merupakan prosedur yang sulit, pelaksanaan liposuction memerlukan perencanaan yang matang dan pengamatan yang artistik untuk memperoleh hasil pasca operasi yang memuaskan (Gambar 1, 2). ${ }^{1,2,6}$ Dengan menggunakan suatu tube stainless steel kecil (cannula) (Gambar 3, 4) yang dihubungkan dengan suatu alat sedot (suction unit) yang cukup kuat, yang dimasukkan ke dalam jaringan lemak tubuh melalui satu insisi kecil pada kulit. ${ }^{3,6}$ Lemak akan disedot keluar sehingga akan menghasilkan bentuk tubuh yang diinginkan, kemudian luka insisi yang kecil tadi akan berkontraksi dengan meninggalkan bekas parut yang 
kecil. ${ }^{6}$ Liposuction dapat dilakukan dengan anaestesi umum atau dengan anestesi lokal disertai sedasi yang agak berat. ${ }^{4,5,8-10}$ Seleksi pasien yang ketat dan tehnik operasi yang sesuai akan menghindari terbentuknya kontur tubuh yang ireguler. Selain itu perawatan perioperasi akan menghindari terjadinya komplikasi pasca operasi. ${ }^{2,3,7}$
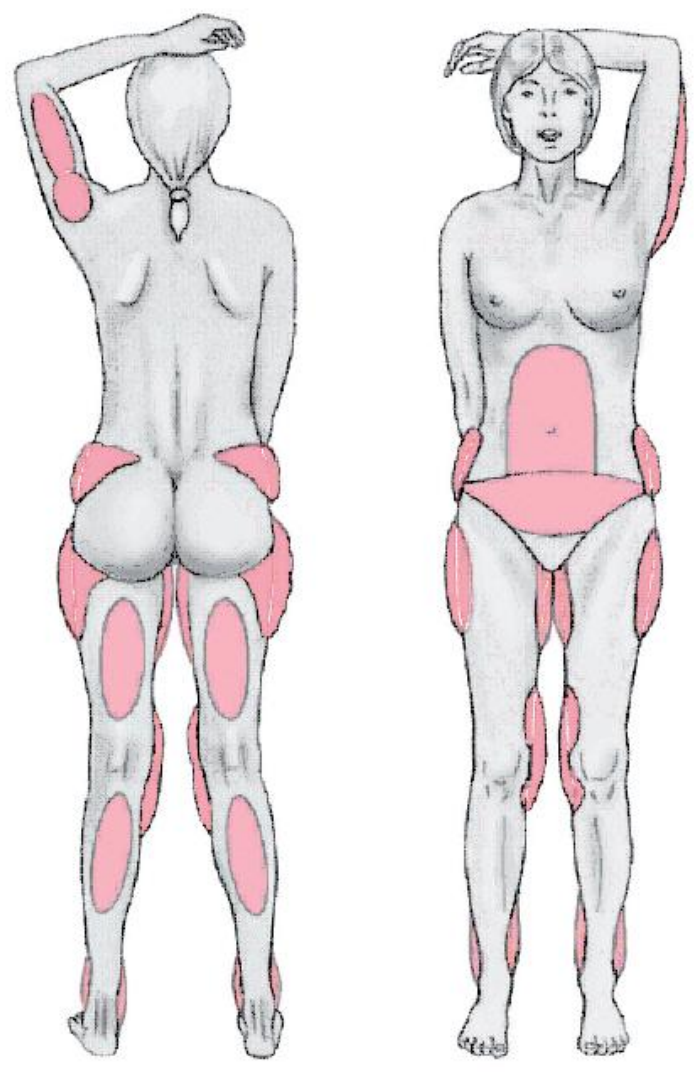

Gambar 1. Area-area pada tubuh yang dapat dilakukan liposuction. ${ }^{6}$
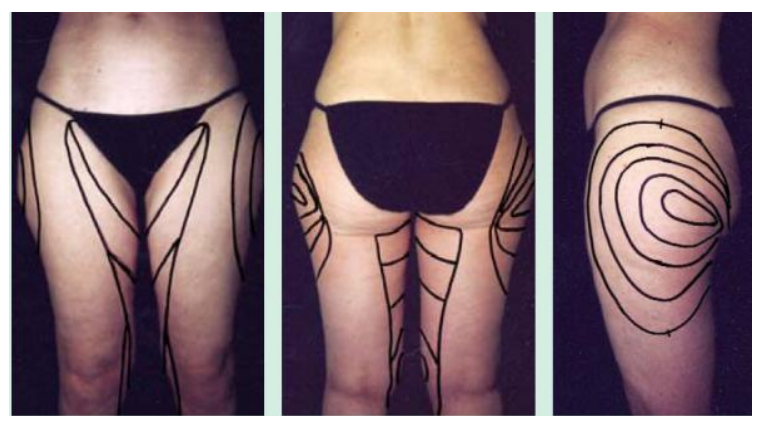

Gambar 2. Bagian-bagian tubuh ditandai dahulu sebelum dilakukan liposuction dengan menggunakan tumescent local anaesthesia. ${ }^{1}$

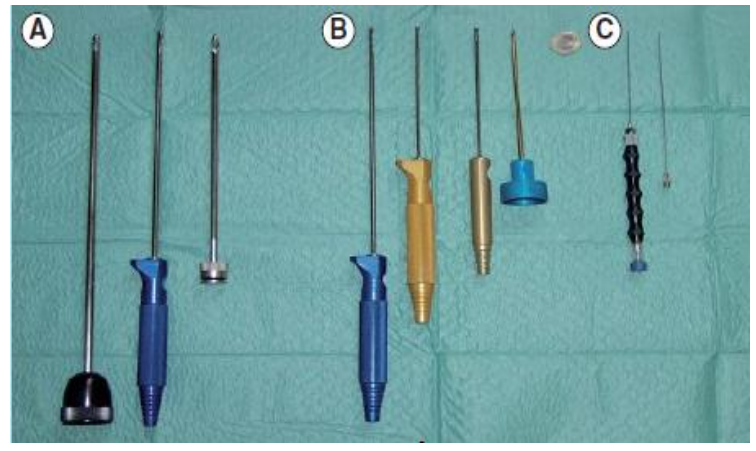

Gambar 3. Berbagai jenis cannula yang dipakai untuk (A) lipoaspiration, (B) liposculpture, dan (C) laser lipolysis. ${ }^{6}$

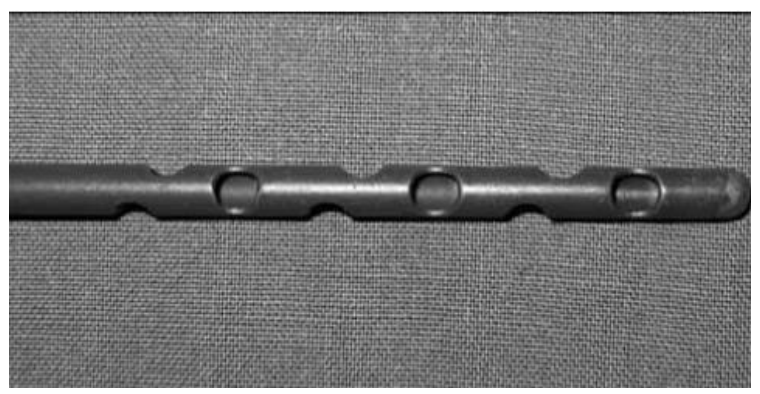

Gambar 4. Cannula yang dipakai biasanya Lipomatic berukuran 4 dengan ujung yang menggelembung dan mempunyai banyak lubang. Gerakan memutar dari kepalanya dan adanya lubang yang banyak memungkinkan pengeluaran lemak yang optimal pada saat dilalui cannula. ${ }^{3}$

\section{SEJARAH LIPOSUCTION}

Prosedur liposuction telah dikenal sejak lebih dari 30 tahun. Tehnik melakukan liposuction diawali dengan cara sederhana, dan sejalan dengan perkembangan teknologi maka prosedur liposuction telah menggunakan alat-alat canggih dengan tingkat keamanan dan kenyamanan yang tinggi. ${ }^{10-13}$

Dipelopori oleh Georgio dan Arpad Fischer, 1974, yang melakukan curettage janin dengan menggunakan suction (cellulosuction tome). Illouz GY, 1977, menggunakan kanula tumpul untuk menyedot lemak dengan membuat terowongan/tunnel kecil yang mencapai ke dalam jaringan lemaknya (tehnik kering). Klein J, 1985, memelopori penggunaan anestesia lokal lidokain $35 \mathrm{mg} / \mathrm{kg}$ berat badan yang dikombinasi dengan epinefrin dan melakukan 
liposuction dengan tehnik basah/tummescent. Perkembangan lanjut oleh Zocchi M, 1992, yang melakukan liposuction dengan tehnik ultrasonik (Ultra Sound Assisted Lipoplasty, UAL). Pada 1999 diperkenalkan metode Vibration Amplification of Sound Energy at Resonance (VASER) dimana lemak diemulsikan dengan menggunakan energi gelombang suara, dan dilanjutkan dengan liposuction. Kemudian pada tahun 2000 diperkenalkan tehnik external ultrasound (ultra shape), dan selanjutnya pada 2002 tehnik mesotherapy (injection lipolysis). ${ }^{13}$

Perkembangan pesat dalam tehnik operasi membuka peluang untuk lebih banyak tempat di dalam tubuh yang dapat dilakukan pengangkatan/penyedotan lemak dengan lebih mudah, lebih sedikit kehilangan darah pada saat operasi, menurunnya ketidaknyamanan, serta tentunya menurunnya resiko yang terjadi. ${ }^{10,11}$

\section{TEHNIK OPERASI MENGELUARKAN LEMAK}

Dewasa ini telah dikenal berbagai tehnik operasi untuk mengeluarkan lemak dari dalam tubuh. Berbagai alasan yang dikemukakan untuk dilakukan tindakan operasi ini, antara lain kesehatan dan kosmetik. Pilihan tehnik operasi disesuaikan dengan alasan tersebut dan keadaan pasien, yaitu seberapa banyak jaringan adiposa yang akan dikeluarkan. Tehnik operasi yang telah digunakan adalah abdominoplasty lipectomy, mesotherapy (injection lipolysis), external ultrasound (ultra shape), Suction assisted lipoplasty (SAL), Power assisted liposuction (PAL), Ultrasound assisted lipoplasty (UAL), body sculpting (smartlipo) dengan menggunakan Laser assisted liposuction (LAL), radio frequency (thermage), dan VASSER. ${ }^{14-18}$ Dengan berkembangnya tehnik operasi maka lebih banyak lagi area pada tubuh yang dapat dilakukan liposuction (Gambar 1). Sebelum dilakukan liposuction, bagian-bagian tubuh yang akan dilakukan tindakan terlebih dahulu ditandai dengan pena yang waterproof dengan pasien dalam posisi berdiri (Gambar 2).,2,6

\section{Abdominoplasty lipectomy}

Pada tehnik ini dilakukan insisi kulit yang luas untuk dapat mengeluarkan dengan pisau semua jaringan lemak yang dimaksud. ${ }^{5,19}$

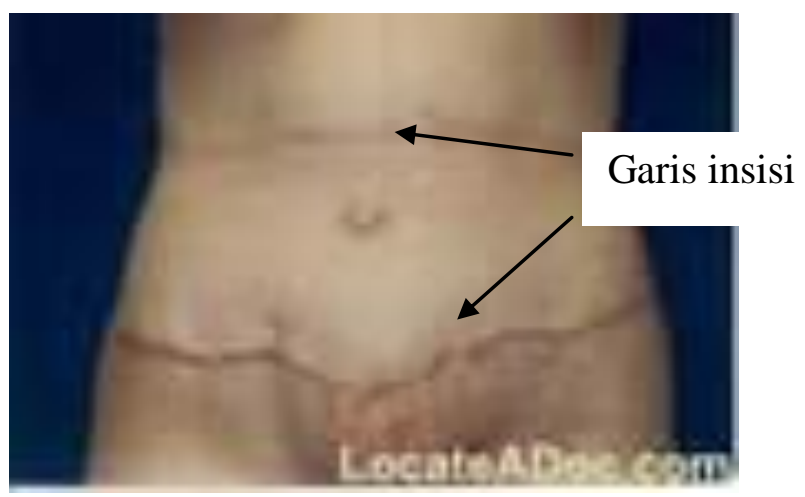

Gambar 5. Pasca abdominoplasty lipectomy dengan bekas garis insisi. ${ }^{5}$

\section{Mesotherapy (Injection lipolysis)}

Berawal pada tahun 2002 dimana thenik ini digunakan untuk mengobati penyakit systemic lipo-dissolve. Dilakukan lisis sel lemak dengan menggunakan suntikan phosphatidyl choline/deoxycholate based. Mesotherapy berkembang sebagai tehnik yang menggunakan penyuntikan bahan-bahan tertentu pada daerah tertentu di bawah kulit. $^{12,17,19}$

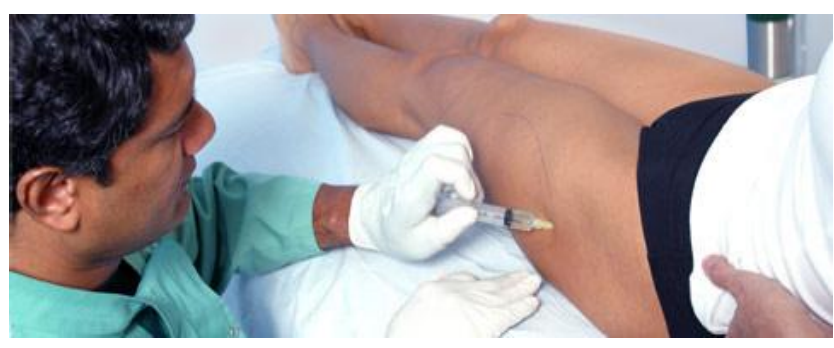

Gambar 6. Tindakan mesotherapy dengan penyuntikan.

\section{External ultrasound (Ultra Shape)}

Tindakan ini dilakukan dengan menggunakan ultrasound dari luar tubuh, tidak invasif dan tanpa tindakan operasi, sayatan, atau suntikan. Dengan tindakan ini jaringan lemak dapat dihancurkan tanpa merusak ja- 
ringan lainnya. Tindakan ini tidak disarankan oleh Food and Drug Administration (FDA). ${ }^{15}$

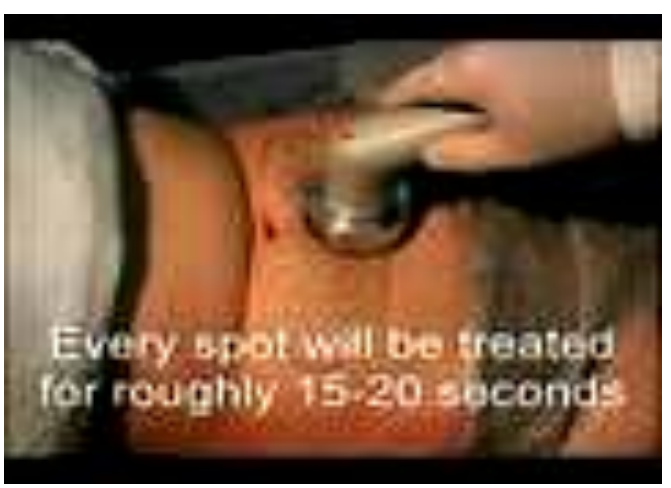

Gambar 7. Tindakan external ultrasound. ${ }^{15}$

\section{Suction-assisted lipoplasty (SAL)}

Tindakan ini dilakukan dengan menggunakan alat sedot (suction unit) yang dimasukkan ke dalam jaringan lemak untuk menyedot lemak secara tidak selektif. Gerakangerakan dengan alat sedot dilakukan oleh pembedah, tetapi akan terjadi banyak kerusakan jaringan, pembuluh darah, saraf, dan jaringan lunak. Tindakan ini berpotensi mengakibatkan permukaan kulit menjadi tidak rata, dan digunakan khusus untuk debulking lemak yang dalam dan intermedia. ${ }^{15,16,19}$

\section{Power-assisted liposuction (PAL)}

Tindakan ini dilakukan dengan menggunakan kanula khusus yang halus. Dilakukan gerakan fibrasi yang cepat dengan menggunakan mesin untuk menghancurkan lemak sehingga dapat disedot ke luar dari tubuh. Avulsi lemak ini tidak selektif dan banyak terjadi kerusakan jaringan. Prosedur ini sangat berpotensi mengakibatkan trauma pada tubuh penderita. ${ }^{1,5}$

Keuntungannya adalah selain untuk menyedot juga terjadi pergerakan bolakbalik oleh mesin yang kurang tergantung pada fisik pembedah, serta tindakan dapat dilakukan lebih cepat dibandingkan dengan SAL. ${ }^{1,5}$

\section{Ultrasound-assisted lipoplasty (UAL)}

Pada tindakan ini penggunaan gelombang ultrasonik membantu penyedotan lemak, tetapi tidak menjadi lebih cepat. Keuntungan utamanya adalah karena penghancuran lemak yang dibantu USG kemudian diikuti oleh penyedotan lemak. Selain itu biasanya kurang terjadi kerusakan jaringan dan pendarahan, lagi pula volum lemak yang dapat disedot cukup besar. ${ }^{5,16}$

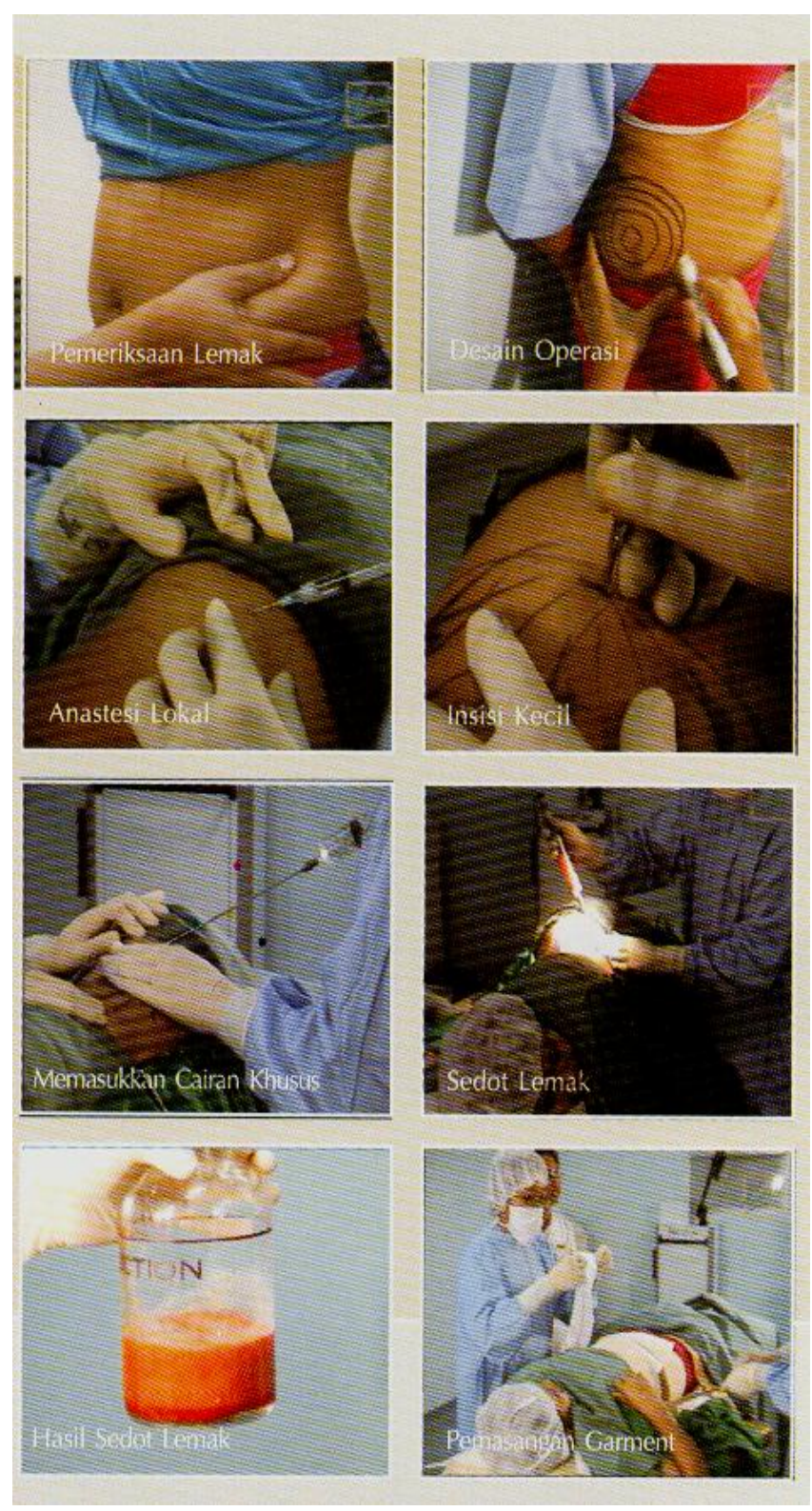

Gambar 8. Tindakan suction-assisted lipoplasty (SAL) dengan menggunakan alat sedot. 


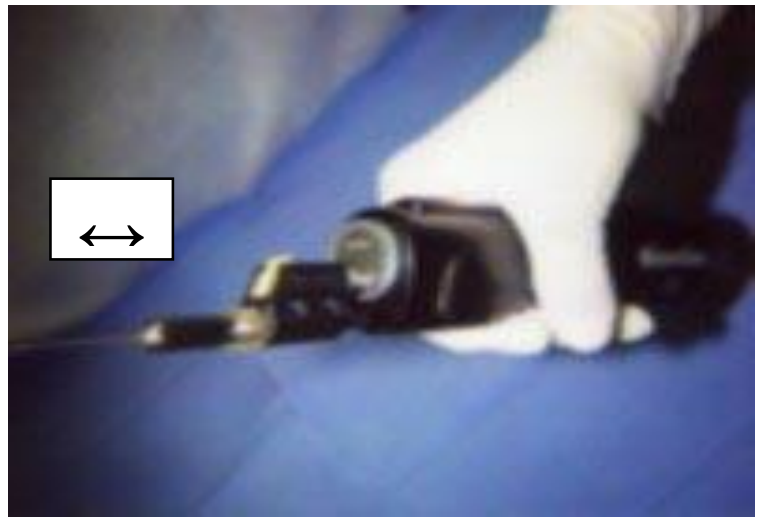

Gambar 9. Tindakan Power-assisted liposuction dengan menggunakan mesin yang bergerak bolak balik.

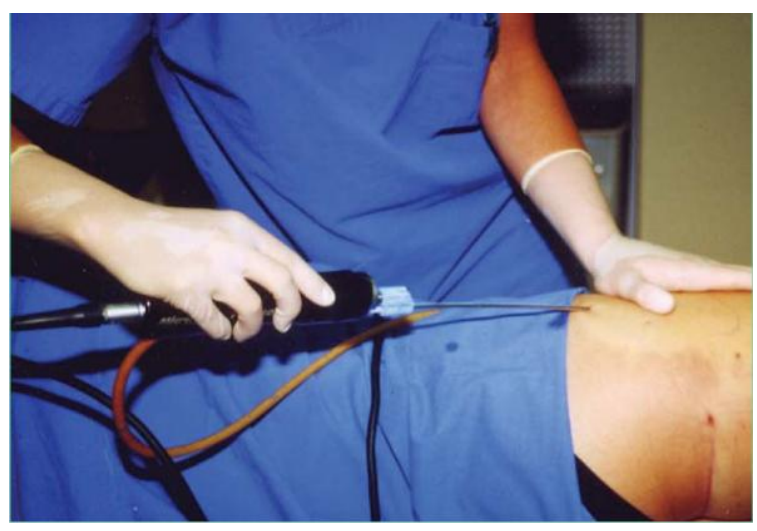

Gambar 10. Power-assisted liposuction. Motor yang digenggam menyebabkan vibrasi cannula. Tampak lemak yang disedot di dalam tube. ${ }^{1}$

\section{Body sculpting (Smartlipo), LAL (Laser- assisted liposuction)}

Tindakan ini telah diijinkan oleh FDA dan menggunakan Laser-assisted liposuction berfrekuensi $1064 \mathrm{~nm}$ (Nd: YAG Laser). Sangat efektif untuk digunakan pada massa lemak yang kecil atau untuk mengencangkan kulit. Lemak dihancurkan dengan sinar laser yang terdapat pada ujung kanula pengisap, kemudian disedot keluar. 3,12,17,19

Pada kelompok adiposit yang akan dilakukan tindakan terlebih dahulu dimasukkan local tumescent anaesthesia, kemudian cannula laser dimasukkan melalui insisi kecil pada kulit. Denyutan laser diarahkan ke daerah kelompok adiposit, sambil cannula digerakkan pada subkutis dengan arah yang berbolak-balik. Denyut laser yang sangat pendek dengan gelombang tinggi

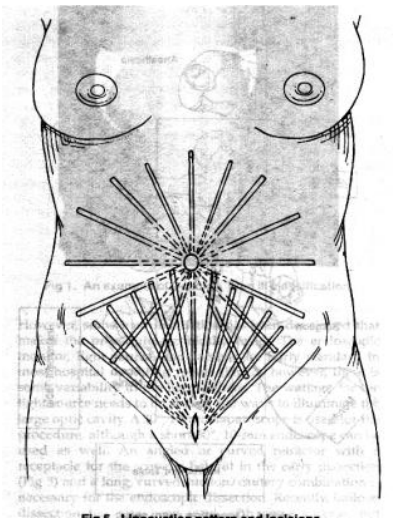

Gambar 11. Tindakan body sculpting dengan menggunakan laser-assisted liposuction pada daerah abdomen.

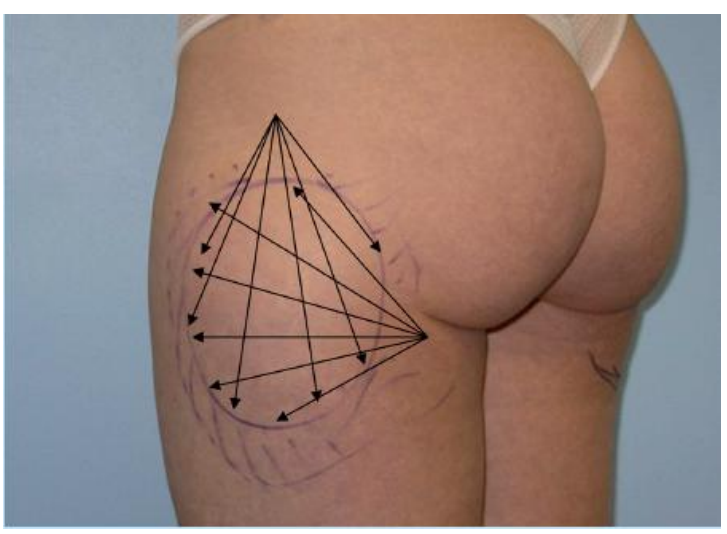

Gambar 12. Posisi cannula selama prosedur lipolisis. $^{6}$

menghasilkan efek fotoakustik yang secara selektif mengakibatkan disintegrasi membran adiposit serta terlepasnya kandungan sel dengan resiko hangus yang minimal. Laser juga mengkoagulasi jaringan untuk memicu pengencangan kolagen dan hemostasis. Efek termolisis dari laser akan menghancurkan jaringan lemak sehingga dapat diaspirasi, baik dengan sedotan jarum suntik atau pompa peristaltik (Gambar 13-16). ${ }^{4}$

\section{Radio frequency (thermage)}

Tindakan ini dilakukan dengan menggunakan kapasitip monopolar radiofrequency (RF), terutama dilakukan untuk mengencangkan kontur kulit. Tindakan ini menggunakan teknologi yang aman yang memberikan pemanasan volumetrik kedalam ku- 


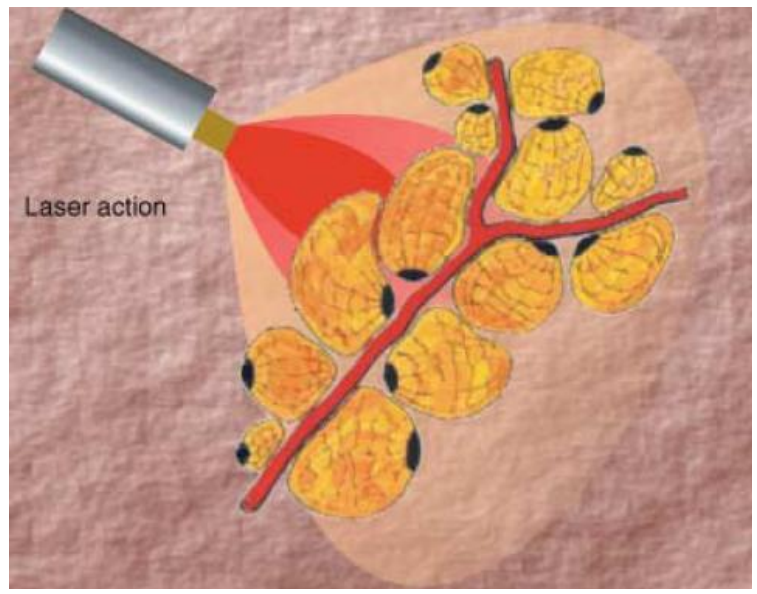

Gambar 13. Kerja laser. ${ }^{4}$

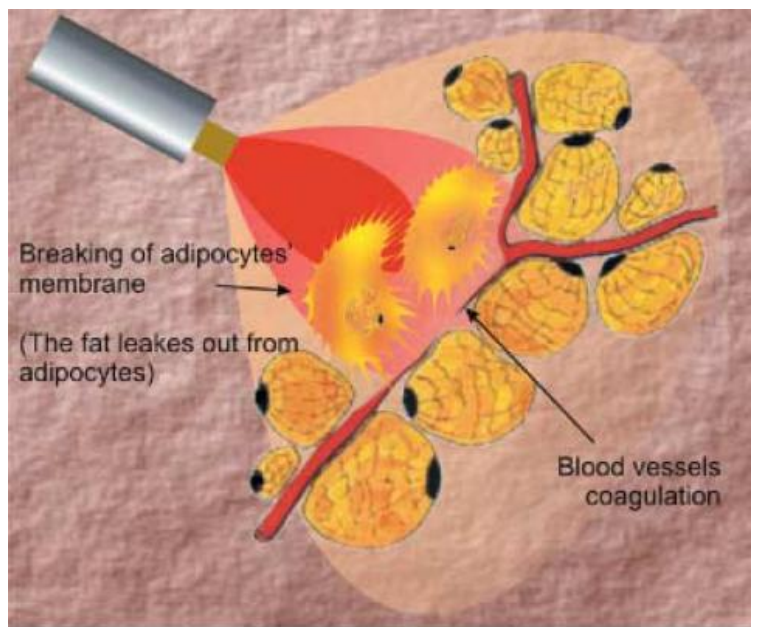

Gambar 14. Pemecahan membran adiposit. ${ }^{4}$

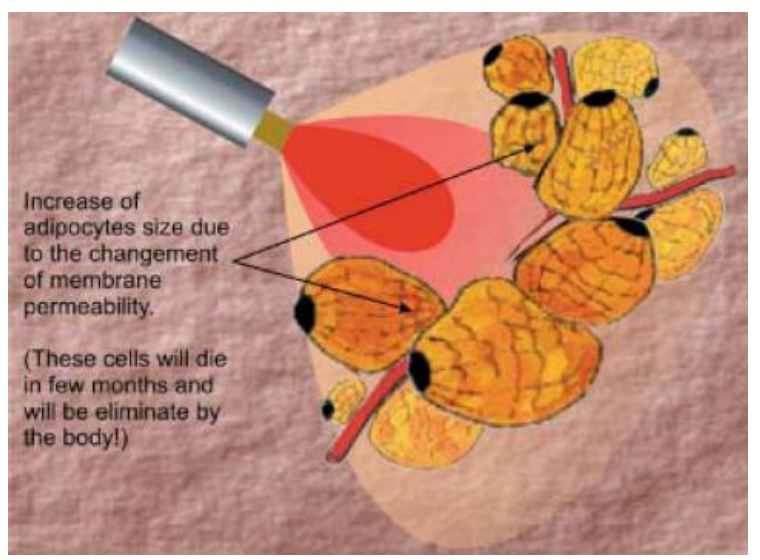

Gambar 15. Pertambahan ukuran adiposit oleh karena perubahan permeabilitas membran (selsel ini akan mati dalam beberapa bulan dan dikeluarkan dari dalam tubuh). ${ }^{4}$

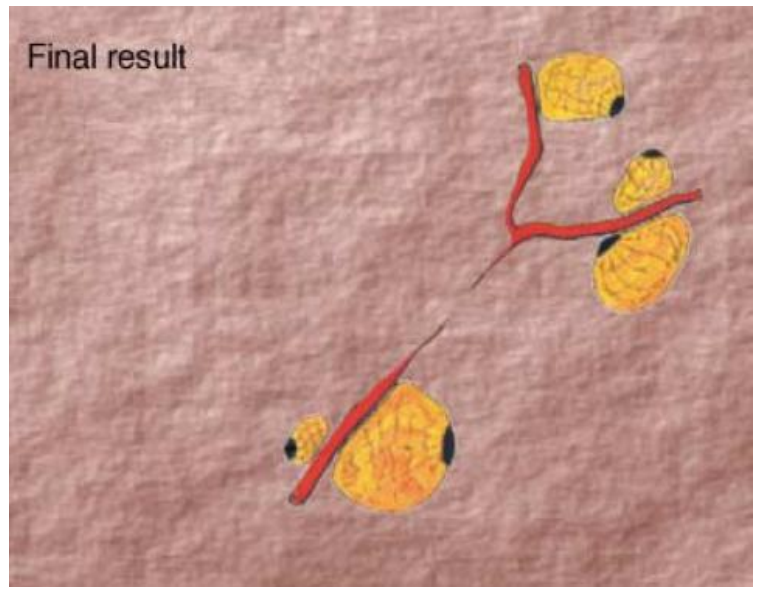

Gambar 16. Hasil akhir. ${ }^{4}$

lit yang kaya kolagen. Pemanasan ini merangsang tubuh untuk memproses pembaruan kulit, membantu mengencangkan kolagen yang ada, dan membentuk kolagen baru. Renovasi kolagen ini membantu menciptakan kulit yang lebih halus dan lebih kencang, sehingga memberikan penampilan yang lebih muda. ${ }^{12,17,19}$

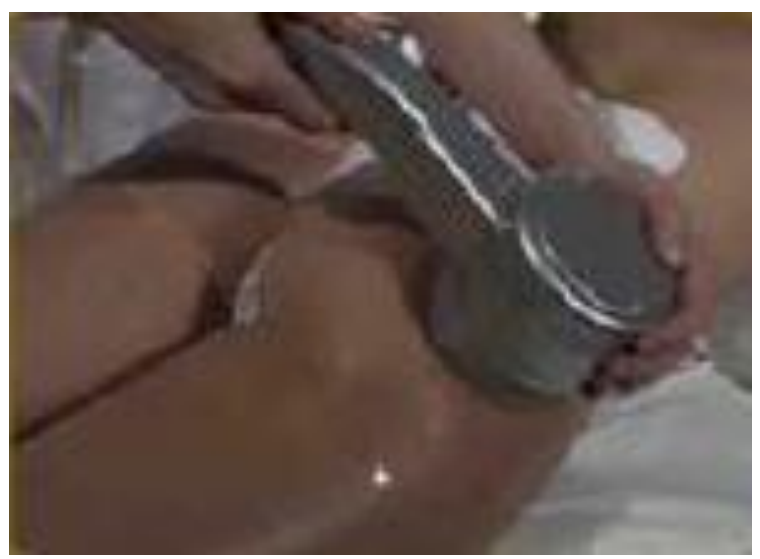

Gambar 17. Tindakan Radiofrequency dengan menggunakan kapasitip monopolar radiofrequency.

\section{VASER}

VASER termasuk Ultrasound Assisted Liposuction (UAL) yang menggunakan gelombang suara untuk mengemulsikan (mencairkan) lemak agar mudah dikeluarkan dari tubuh. $^{17}$ 
Tindakan VASER liposelection terdiri dari tiga tahap. Pada tahap I dilakukan infus ke daerah yang akan diisap lemaknya dengan menggunakan cairan $\mathrm{NaCl}$ fisiologi yang cukup. Selanjutnya pada tahap II dilakukan emulsi lemak dengan sistim energi gelombang suara dari VASSER yang dikeluarkan dari ujung kanula yang dimasukkan ke dalam jaringan lemak. Jaringan lemak yang berkontak akan dihancurkan, sedangkan jaringan-jaringan lainnya relative tetap intak (liposelective). Pada tahap III lemak dikeluarkan melalui aspirasi dengan menggunakan kanula. ${ }^{12,17,19}$

\section{ANAESTESI YANG DIGUNAKAN PA- DA LIPOSUCTION}

Perkembangan tehnik operasi liposuction juga diikuti dengan perkembangan tehnik anestesia. Jeffrey Klein seorang ahli farmakologi klinik dan ahli penyakit kulit (clinical pharmacologist and dermatologist), 1985, yang pertamakali menggunakan anaestesi lokal pada saat melakukan liposuction. Kemudian pada tahun 1987 ia mengembangkan tehnik anaestesia yang disebut tumescent local anesthesia dengan menggunakan lidokain dosis $35 \mathrm{mg} / \mathrm{kg}$ berat badan. ${ }^{13,20,21}$ Cara pembuatan tumescent terdiri dari lima tahap: 1) 1 liter saline atau Ringer lactate solution, 2) tambahkan lidokain 500-1000mg (10-20 ampul), 3) tambahkan epinefrin $1 \mathrm{gr}$ atau $1 \mathrm{cc}$ (1ampul), 4) tambahkan NaHCO3 12,5 ml (10 meq/L), dan 5) bisa ditambahkan triamcinolone 10 mg. Dengan demikian dosis lidokain yang digunakan berkisar $5-10 \mathrm{mg} / \mathrm{kg}$ berat badan, dengan konsentrasi $0,4-0,8 \%$, sedangkan untuk konsentrasi epinefrin $1 \mathrm{~g} / 1000 \mathrm{ml}$ $(1 \mathrm{mg} / 1.000 .000 . \mathrm{ml})$ yaitu $1 / 1.000 .000 .^{1,20-23}$

Selanjutnya Lillis, 1988, melaporkan bahwa dengan tehnik ini ternyata kurang dari $1 \%$ yang mengalami pendarahan. Pada tahun 1996 Moy melaporkan penggunaan lidokain untuk anaestesi lokal dengan dosis $55 \mathrm{mg} / \mathrm{kg}$ berat badan. ${ }^{15,19}$

Umumnya untuk anaestesi lokal digunakan lidokain $1 \%$ dosis $1-10 \mathrm{mg} / \mathrm{kg}$ berat badan, tetapi untuk liposuction digunakan lidokain sampai $45 \mathrm{mg} / \mathrm{kg}$ berat badan untuk orang kurus, $50 \mathrm{mg} / \mathrm{kg}$ berat badan untuk orang normal atau gemuk dengan penurunan $10 \%$ untuk laki-laki. Gejala toksik terjadi bila batas lidokain serum melebihi 60 $\mathrm{mg} / \mathrm{L}$. Pernah dilaporkan kasus yang meninggal pada pemberian dosis lidokain 75 $\mathrm{mg} / \mathrm{kg}$ berat badan. ${ }^{5,21,22}$
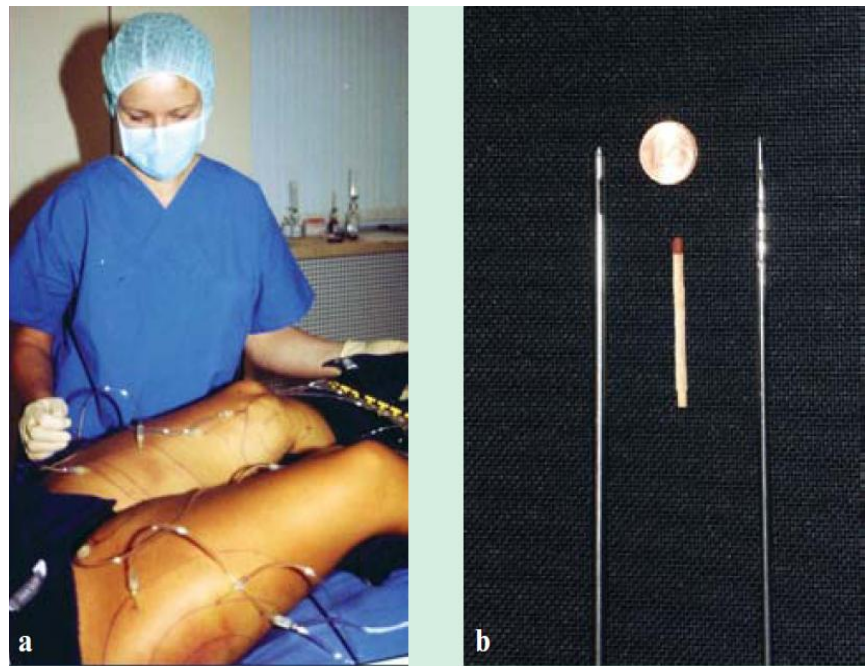

Gambar 18. a. Infiltrasi larutan tumescent pada bagian dalam dan luar paha. b. perbandingan ukuran microcannula berujung tumpul. ${ }^{1}$

Tabel 1. Pemilihan jenis liposuction berpatokan pada ketegangan kulit perut (laxidity), lemak perut (fat volume), serta keadaan otot perut (flaxidity). ${ }^{17,18}$

\begin{tabular}{ccccc}
\hline Tipe & $\begin{array}{c}\text { Laxidity } \\
\text { Kulit }\end{array}$ & $\begin{array}{c}\text { Volum } \\
\text { Lemak }\end{array}$ & $\begin{array}{c}\text { Flaxidity } \\
\text { Otot }\end{array}$ & Penanganan \\
\hline I & minimal & bervariasi & minimal & SAL \\
II & mild & bervariasi & mild & Mini lipectomy \\
III & moderate & bervariasi & moderate & Moderate lipectomy \\
IV & severe & bervariasi & severe & Full/standard lipectomy \\
\hline
\end{tabular}




\section{PEMILIHAN JENIS TINDAKAN OPE- RASI LIPOSUCTION}

Penanganan terhadap lemak perut adalah berdasarkan bentuk/tipe tertentu dengan berpatokan pada ketegangan kulit perut (laxidity), keadaan lemak perut (fat volume), serta keadaan otot perut (flaxidity). ${ }^{17,18}$

\section{KESIMPULAN}

Dewasa ini liposuction dilakukan atas indikasi kesehatan dan kosmetik. Tehnik operasinya telah berkembang pesat sehingga lebih besar volum lemak di dalam tubuh yang dapat dikeluarkan dengan lebih mudah, lebih sedikit terjadi kehilangan darah, serta lebih kurang ketidak nyamanan dan resiko. Pemilihan tindakan operasi berpatokan pada beberapa hal yaitu ketegangan kulit perut (laxidity), keadaan lemak perut (fat volume), serta keadaan otot perut (flaxidity).

\section{DAFTAR PUSTAKA}

1. Schmeller W. Liposuction. [homepage on the internet]. Nodate. [cited $2010 \mathrm{Sep}$ 20]. Available from: http://www.hanseklinik.com/englisch/Liposuction.pdf.

2. Gabriel A. Large Volume Liposuction, safety and indications. [homepage on the internet]. c2010. [updated Jan 14 2010; cited 2010 Sep 20]. Available from: http://emedicine.medscape.com/article/1 272958-overview.

3. Heymans O, Castus P, Grandjean FX, D Van Z. Liposuction: review of the techniques, innovations and applications. Acta chir belg. 2006;106:647-653.

4. Katz B, McBean J. The new laser liposuction for men. Dermatologic Therapy. 2007;20:448-451.

5. Venkataram J. Tumescent liposuction: A Review. Journal of Cutaneous and Aesthetic Surgery. Jul-Dec 2008;1(2).

6. Mordon S, Plot E. Laser lipolysis versus traditional liposuction for fat removal. Expert Rev. Med. Devices. 2009;6(6): 677-688.

7. ASLSS, AACS. 2006 Guidelines for Liposuction Surgery. [homepage on the internet]. Nodate [cited 2010 Sep 20]. Available from: http://www.cosmetic- surgery.org/surgeons/2006_liposuction_ guidelines.pdf.

8. Venkataram M. Tumescent liposuction: Standard guidelines of care. Indian $\mathrm{J}$ Dermatol Venereol Leprol. 2008;74:5460.

9. Markman B, Barton FE. Anatomy of subcutaneous tissue of the trunk and lower extremity. Plast. Reconstr. Surg. 1986;80(2):248.

10. Charles E. Hughes III. Reduction of lipoplasty Risks and Mortality: An ASAPS Survey. Aesthetic Surg J. 2001;21(2):120-127.

11. Gingrass MK. Lipoplasty Complica-tions and Their Prevention. Clin Plast Surg. 1999;26(3):341.

12. Jewell ML. Patient-Savety Data: How It Can Improve Our Performance. Aesthetic Surgery Journal. 2004;24(4):1-3.

13. Flynn T. The History of Liposuction. Dermatol Surg. [serial online]. 2000 [cited 2010 Okt 10]; 26(6):515-520. Available from: http://www.hautarztduesseldorf.de/de/person/artikel/history_ of_liposuction_en.pdf.

14. What is Liposuction. Ceatus Media Group LLC. [homepage on the internet]. c2010 [updated Feb 17; cited 2010 Oct 10]. Available from: http://www.liposuction4you.com/whatisliposuction.htm.

15. Lillis $\mathbf{P}$. Liposuction surgery under local anesthesia: Limited blood loss \& minimal lidocaine absorption. $\mathbf{J}$ Dermatol Surg Oncol. 1988;14:1 145-8.

16. Rohrich RJ, Beran SJ, Kenkel JM. Ultrasound-assisted liposuction. Quality Medical Publishing Inc, 1998.

17. Rohrich RJ. The key to long-term success in liposuction: A guide for plastic surgeons and patients. Plast. Reconstr Surg. 2004;11:1945.

18. Everson RE, Denis J. Lynch and the ASPS committee on patient safety: Practice advisory on liposuction. Plast Reconstr Surg. 2004;113:1478.

19. Lillis P. Tumescent anesthesia. In:Roenigk \& Roenigk's Dermatologic Surgery: Principles and Practice. $2^{\text {nd }}$ ed. New York: Marcel Dekker, 1966.

20. Brown SA, Lipschitz AH. Pharmacokinetics and safety of epinephrine user in liposuction. Plast. Reconstr Surg. 2004;114: 756.

21. Vaughan TM, Burt J. Local anesthetic. 
150 Jurnal Biomedik, Volume 1, Nomor 3, November 2009, hlm. 142-150

Selected Readings in Plast Surgery. 1999;9(4).

22. Bill TJ. Lidocaine methabolism: Pathophysiology, drug interaction, and surgical implications. Aesthetic Surg. J.
2004;24:307-11.

23. Klein J. Tumescent technique for regional anesthesia permits lidocaine doses of 35 $\mathrm{mg} / \mathrm{kg}$ for liposuction. J Dermatol Surg Oncol. 1990;16:3. 